\title{
耳下腺腫瑒の臨床的検討ならびに腫瘍被膜の 被包状態についての組織学的検誩
}

\section{譚包生・松浦 正朗**佐藤 淳 - ** \\ Clinical evaluation of parotid tumors and histological investigation of tumor capsulation}

\author{
Baosheng TAN $\cdot$ Masaro MatsuUra ${ }^{*} \cdot$ Junichi Sato ${ }^{* *}$
}

\begin{abstract}
From 1987 through 1996, 258 parotid tumors were treated at Beijing Stomatological Hospital. In this series, 219 cases were benign and 39 were malignant. Of the benign tumors, 141 were pleomorphic adenomas, and 49 were Warthin's tumors. The other 29 cases consisted of 7 monomorphic adenomas, 6 basal cell adenomas, 6 myoepitheliomas, and 10 nonepithelial tumors.

The clinical characteristics of patients with pleomorphic adenomas were compared with those of patients with Warthin's tumors. The average age of patients with Warthin's tumors was higher than that of patients with pleomorphic adenomas (60.1 years vs. 39.5 years). Pleomorphic adenomas were more frequent in females than in males (1.39: 1), whereas Warthin's tumors were more connor in males than in females $(5.13: 1)$. The proportion of smokers among patients with Warthin's tumors was higher than that among patients with of pleomorphic adenomas $(96.9 \%$ vs. $50.0 \%)$. These three factors differed significantly between the two types of tumors.

The malignant tumor group included 8 mucoepidermoid carcinomas, 7 carcinomas in pleomorphic adenomas, 6 adenocarcinomas, 6 acinic cell carcinomas, 4 adenoid cystic carcinomas, and 4 papillary cyst adenocarcinomas.

All tumors were treated by surgery. Total parotidectomy was performed for 22 of the 39 malignant tumors, superficial parotidectomy was performed for 16 cases, and deep lobectomy was performed for 1 cases. In patients with pleomorphic adenomas and Warthin's tumors, local excision of the tumors was performed for 16 cases, superficial parotidectomy for 169 cases, superficial parotidectomy with partial deep lobectomy for 4 cases and partial resection of the parotid gland including the tumor for 1 case.

The facial nerve was exposed from the truncus to the branches in 85 cases and from the branches to the truncus in 88 cases. Weakness of the facial nerve occurred in 29 patients immediately after surgery, but recovered within a few weeks. No difference was noted in the occurrence of nerve disturbance between the two groups.
\end{abstract}

首都医科大学附属北京口腔医院口腔顎顔面外科

(主任 : 朱宣智教授)

*福岡歯科大学口腔インプラント科

(主任 : 松浦正朗教授)

**鶴見大学歯学部口腔外科学第一講座

(主任 : 瀬戸晥一教授)

Department of Oral and Maxillofacial Surgery, Faculty of Stomatology, Capital University of
Medical Science (Chief: Prof. Xuanzhi Zhu)

*Department of Oral Implantology, Fukuoka Dental Collage (Chief: Prof. Masaro Matsuura)

**The First Department of Oral and Maxillofacial Surgery, School of Dentistry, Tsurumi University (Chief: Prof. Kanichi Seto)

受付日: 平成11年 1 月 27 口 
Complete encapsulation of the tumor was observed in $73.8 \%$ of pleomorphic adenomas and $70.5 \%$ of Warthin's tumors, and no encapsulation was found in 1 Warthin's tumor and all 8 mucoepidermoid carcinomas. Tumor cells invaded into the capsule in $41.8 \%$ of pleomorphic adenomas. In conclusion, an adequate surgical margin is needed in parotid tumor surgery even in patients with benign tumors.

Key words: parotid tumor (耳下腺腫瘍), tumor capsule formation (腫瘍被膜形成), pleomorphic adenoma (多形性腺腫), Warthin's tumor (Warthin 腫瘍)

\section{緒 言}

中国では耳下腺腫瘍は口腔外科の一般的な疾患の 1 つであるが, 日本では耳下腺腫瘍が口腔外科で治療さ れることは比較的まれである.一方, 中国では多数例 の耳下腺腫瘍の臨床報告がみられるが, 耳下腺腫瘍の 発生頻度や病理組織型別症例数等の疫学的項目を生活 環境や習慣が異なる中国国内各地方および日本や諸外 国のそれと比較した報告は少なく，その実態は明らか にされていない.最近は MRI, CT エックス線写真, エコー等の画像診断に加え針生検による診断法が発達 し, 比較的正確な術前診断が得られるようになった。 しかし, 従来, 耳下腺腫瘍は解剖学的位置の特殊性か ら, 生検が行いにくく、要臨床所見に 加えエックス線造影写真の所見から手術法を決定して きた、本論文では口回空 顎顔面外科で手術を施行した症例について臨床的なら びに疫学的検討を加えるとともに, 主として多形性腺 腫とWarthin 腫場の腫湯実質を被包している被膜の 形成状態を観察し, 従来行ってきた手術法選択の妥当 性について検討した.

\section{材料ならびに方法}

1987年から1996年までの10年間に医科大学附属 —医院口腔顎顔面外科で治療を行った耳下腺腫 瘍258例を検討の対象とした。患者の居住地は 内が258例中 194 例 $(75.2 \%)$ を占め, 次いで】を取 り囲む例 $(13.2 \%)$ ，その他が30例であった (表 1 ).

手術切除材料のヘマトキシリンエオジン染色全割切 片標本が揃っていた多形性腺腫122例, Warthin 腫瘍 44例, 粘表皮癌 8 例について, 腫瘍全周の被膜の形成 状態を検鏡観察した。標本は摘出物から腫瘍周囲に正 常腺組織をつけて切り出し, $2 \sim 3$ 枚の全割切片を製 作した. 検体が大きい場合には腫瘍周囲の被膜の有無 を肉眼で観察し, 被膜の存在が不明確な部分があれば, そこを含むように標本を製作した. 粘表皮癌の腫瘍細 胞の正常組織内への浸潤距離は，オリンパス UMDOB 型光学顕微鏡を用い視野内の矢印を正常組織 と腫瘍組織の内側境界に合わせ, そこから浸潤した腫
崵細胞の最外側端まで移動させ, 切片の移動距離を接 眼レンズ内に入れた格子の数で計測し，これを倍率で 割って算出した.

唾液腺腫瘍の分類は1991年の WHO 分類 ${ }^{1)}$ に従っ た。

対象患者の腫瘍の組織型と手術法, 年齢, 性別, 喫 煙習慣, 職業等との関係については $\mathrm{t}$ 検定およびカイ 2 乗検定を用いて統計的検討を行った。

\section{結果}

耳下腺腫瘍258例のうち良性腫瘍は219例（84.9\%）, 覀性腫瘍は39例（15.1\%）と5.6対 1 の比率であった. 以下良性腫瘍と悪性腫瘍に分けて分析した。

\section{1. 良性腫瘍}

良性腫瘍患者の性別は男女ほぼ同数で, 年齢は 10 歳 未満 2 例, 10 代 12 例, 20 代 24 例, 30 代 50 例, 40 代 43 例, 50 代44例, 60代35例, 70代が 9 例であった. 病理組織型別 では多形性腺腫と Warthin 腫瘍が大部分を占め，そ の他の上皮性腫瘍が19例, 非上皮性腫瘍が10例であっ た (表 2 ).

\section{(1) 多形性腺腫 (表 3 )}

多形性腺腫141例のうち, 一次症例は 122 例, 他院で 治療後再発して来院した二次症例は19例 (13.5\%) で あった. 患者の年齢は最年少 10 歳, 最高齢75歳で, 20 代 から40代のものが多く, 平均年齢は39.5歳であった. 性別では男性よりも女性が多かった。

異常を自覚してから来院までの期間は，1 か月以内 が 5 例, 1 か月を越えて 1 年以内が 46 例, 1 年を越え て 3 年以内が36例で, 5 年以上経過してから来院した ものが36例あった. 患者の職業別では, 工場労働者が

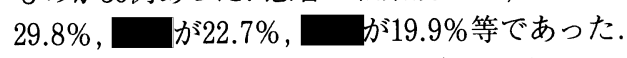

腫瘍の部位は耳介下部が最も多く, 次いで耳前部, 耳後部の順で, 両側に発症したものはなかった.

( 2 ) Warthin 腫瘍 (表 4)

Warthin 腫瘍は全例一次症例であった. 年齢は最年 少が38歳, 最年長は72歳, 平均 60.1 歳で, 50 代, 60 代が 多く, 性別では男女比 5 対 1 と男性に多かった.

異常を認めてから来院までの期間は，1 か月以内が 4 例， 1 か月を越えて 6 か月以内が 19 例で， 2 年以内に 
表 1 耳下腺腫瘍患者の居住地

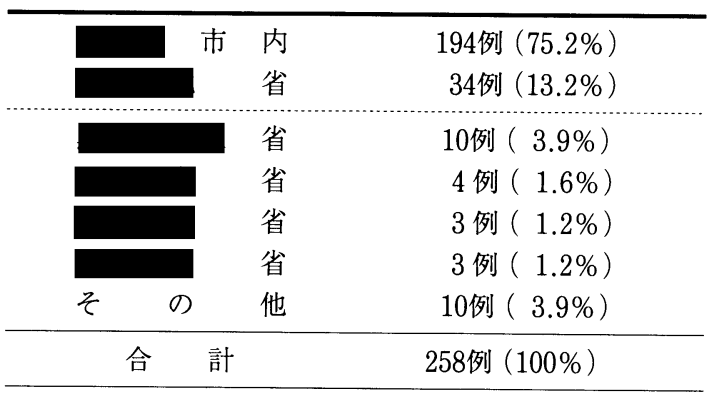

表 2 耳下腺良性腫瘍の病理組織型別症例数 患者の性別および発生部位

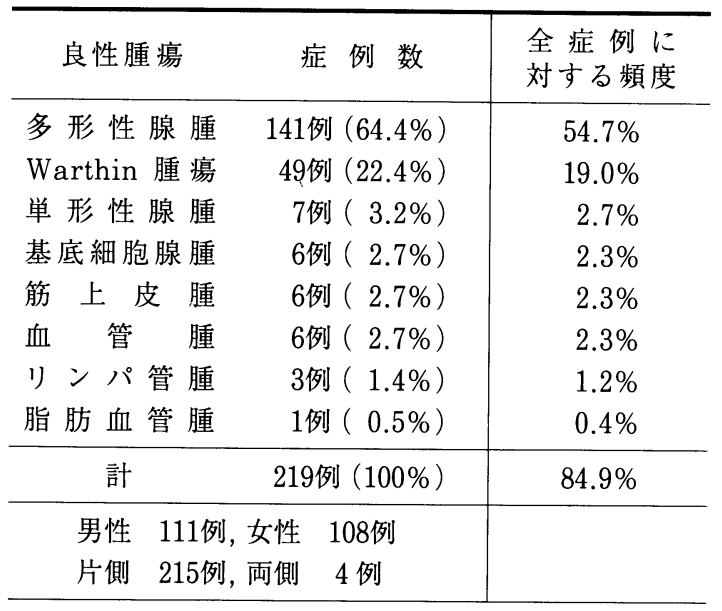

来院したものが大部分を占めていたが，5年以上経過 してから来院したものも8例みられた。

患者の職業別では, 幹部が $57.1 \%$, 労働者は $26.5 \%$, 農民は6.1\%等で, 幹部が過半数を占めていた。

腫瘍の部位は, 耳介下部が最も多く, 次いで耳後部, 耳前部の順であった。また両側発症例が 4 例あったが, 片側の耳下腺に腫瘍が多発した症例はみられなかった。

(3) 多形性腺腫とWarthin 腫瘍の比較

患者の性別では, Warthin 腫瘍は多形性腺腫にくら べ男性が多く（ $\mathrm{t}$ 検定, $\mathrm{p}=0.05)$, 平均年齢は Warthin 腫瘍が多形性腺腫に比べ20歳以上高く, 有意差が認め られた（ $\mathrm{t}$ 検定, $\mathrm{p}<0.0001)$.

職業別では, 多形性腺腫は幹部が少なく, 労働者, 農民が多かったのに対し，Warthin 腫瘍では幹部が過 半数を占め, 幹部の占める割合で両腫瘍間に差を認め た $(\mathrm{t}$ 検定, $\mathrm{p}=0.05)$. なお幹部とは中央および地方政 府, 国営企業, 軍隊等に関連した公的機関の指導部で 働く人々を指す。
表 3 多形性腺腫141例の患者背景

\begin{tabular}{|c|c|c|}
\hline 患者年齢 & 症例数 & 患者の職業 \\
\hline 10歳未満 & 0 例 $\left(\begin{array}{ll}0 & \%\end{array}\right)$ & 工場労働者 $\quad 42$ 例 $(29.8 \%)$ \\
\hline 10歳台 & 7例（ $5.0 \%)$ & 農 民 32 例 $(22.7 \%)$ \\
\hline 20歳台 & 24 例 $(17.0 \%)$ & 部 28例 (19.9\%) \\
\hline 30歳台 & 45例 $(31.9 \%)$ & 7 例 ( $5.0 \%)$ \\
\hline 40歳台 & 31 例 $(22.0 \%)$ & 4例（ $2.8 \%)$ \\
\hline 50歳台 & 19例 $(13.5 \%)$ & 生 $\quad 4$ 例 ( $2.8 \%)$ \\
\hline 60歳台 & 13例 $(9.2 \%)$ & 9 例 ( $6.4 \%)$ \\
\hline 70歳台 & 2 例 $(1.4 \%)$ & そ の 他 15 例 $(10.6 \%)$ \\
\hline \multicolumn{2}{|c|}{$\begin{array}{c}\text { 平均年歯命 } 39.5 \text { 歳 } \\
\text { (分布 } 10 \sim 75 \text { 歳) }\end{array}$} & $\begin{array}{r}\text { 性別: 男性 59例 } \\
\text { 女性 82例 }\end{array}$ \\
\hline \multicolumn{2}{|c|}{ 来院までの期間 } & 腫瘍の部位 \\
\hline 1 か月以内 & 5 例 $(3.5 \%)$ & 耳 前 部 34 例 $(24.1 \%)$ \\
\hline 6 加以内 & 24 例 $(17.0 \%)$ & 耳介下部 76例 $(53.9 \%)$ \\
\hline 1 年以内 & 22 例 $(15.6 \%)$ & 耳 後 部 29 例 $(20.6 \%)$ \\
\hline 2 年以内 & 20 例 $(14.2 \%)$ & 2 例 $(1.4 \%)$ \\
\hline 3 年以内 & 16例 $(11.3 \%)$ & \multirow{5}{*}{ 片側141例, 両側 0 例 } \\
\hline 4 年以内 & 9 例 $(6.4 \%)$ & \\
\hline 5 年以内 & 9 例 $(6.4 \%)$ & \\
\hline 10年以内 & 24 例 $(17.0 \%)$ & \\
\hline 10年以後 & 12例 $(8.5 \%)$ & \\
\hline
\end{tabular}

表 4 Warthin 腫瘍49例の患者背景

\begin{tabular}{|c|c|c|}
\hline 患者年齢 & 症例数 & 患者の職業 \\
\hline 10歳未満 & 0例 $\left(\begin{array}{ll}0 & \%\end{array}\right)$ & 工場労働者 13 例 (26.5\%) \\
\hline 10歳台 & 0例 $\left(\begin{array}{ll}0 & \%\end{array}\right)$ & 3 例 $(6.1 \%)$ \\
\hline 20歳台 & 0例 $\left(\begin{array}{ll}0 & \%\end{array}\right)$ & 部 28 例 $(57.1 \%)$ \\
\hline 30歳台 & 2例 ( $4.1 \%)$ & 4例（ $8.2 \%)$ \\
\hline 40歳台 & 4 例 $(8.2 \%)$ & 1例 ( $0 \%)$ \\
\hline 50 歳台 & 19例 $(38.8 \%)$ & \\
\hline 60歳台 & 18例 $(36.7 \%)$ & \\
\hline 70歳台 & 6例 $(12.2 \%)$ & \\
\hline \multicolumn{2}{|c|}{$\begin{array}{l}\text { 平均年齢 } \quad 60.1 \text { 歳 } \\
\text { (分布 } 38 \sim 72 \text { 歳) }\end{array}$} & $\begin{array}{r}\text { 性別: 男性 } 41 \text { 例 } \\
\text { 女性 } 8 \text { 例 }\end{array}$ \\
\hline \multicolumn{2}{|c|}{ 来院までの期間 } & 腫痬の部位 \\
\hline 1 か月以内 & 4例 $(8.2 \%)$ & 6 例 $(12.2 \%)$ \\
\hline 6 か月以内 & 19例 $(38.8 \%)$ & 耳介下部 24 例 $(49.0 \%)$ \\
\hline 1 年以内 & 7例 $(14.3 \%)$ & 耳 後 部 17 例 $(34.7 \%)$ \\
\hline 2 年以内 & 8 例 $(16.3 \%)$ & 2例（ $4.1 \%)$ \\
\hline 3 年以内 & 2例 ( $4.1 \%)$ & \multirow[t]{5}{*}{ 片側45例, 両側 4 例 } \\
\hline 4 年以内 & 1例 ( $2.0 \%)$ & \\
\hline 5 年以内 & 0 例 $\left(\begin{array}{ll}0 & \%\end{array}\right)$ & \\
\hline 10 年以内 & 5 例 $(10.2 \%)$ & \\
\hline 10年以後 & 3 例 $(6.1 \%)$ & \\
\hline
\end{tabular}


喫煙習慣の有無をカルテに記載があった多形性腺腫 60例, Warthin 腫瘍32例で比較した（図 1). その結果 Warthin 腫湯では喫煙者は31例 $(96.9 \%)$, 多形性腺腫 では30例 $(50.0 \%)$ で, Warthin 腫瘍で有意に喫煙率 が高かった $\left(\chi^{2}\right.$ 検定, $\left.\mathrm{p}=0.05\right)$.

\section{2 . 悪性腫瘍}

悪性腫瘍39例の病理組織型別症例数は，粘表皮癌 8 例, 多形性腺腫内癌 7 例, 腺癌 6 例, 腺房細胞癌 6 例, 等であった（表 5 ).

悪性腫瘍患者の平均年齢は49.6歳で, 最年少は乳頭 様囊胞腺癌の16歳, 最高齢は腺房細胞癌の76歳であっ

$$
\begin{aligned}
& \text { - smoking } \\
& \square \text { no-smoking }
\end{aligned}
$$

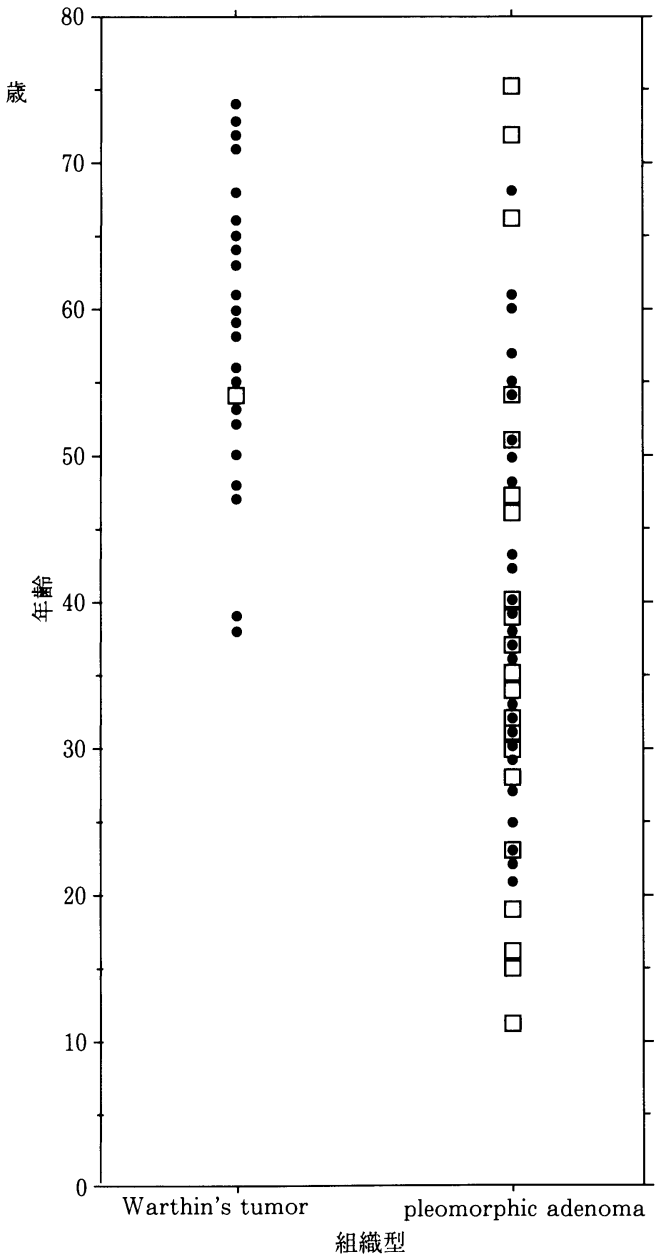

図 1 多形性腺腫瘍と Warthin 腫瘍患者の年齢お よび喫煙の関係
た. 性別は全体では男女差はなかったが, 腺癌, 乳頭 様囊胞腺癌は男性に多く, 腺様囊胞癌は女性のみ, 多 形性腺腫内癌は 7 例中 5 例が女性と, 症例数は少ない が，男女差が大きいものが認められた（表 5 ）。

\section{3. 治療法}

悪性腫瘍, 良性腫瘍ともに手術が一次選択された。 良性, 悪性の術前鑑別診断は, 疼痛の有無, 顔面神経 麻瘏の有無, 腫瘍の生長速度, 触診による癒着の有無, 等の臨床所見および耳下腺造影エックス線写真での造 影剂の導管や腺房からの溢出の有無, 等により行った.

悪性腫瘍39例では浅葉切除が16例, 浅葉と深葉を含 めて耳下腺全摘を行ったもの22例, 深葉のみ切除した ものが 1 例であった. 顔面神経は 3 分の 2 の症例で保 存したが, 残りの症例では顔面神経の一部切除および 全切除が行われた (表 6 ). 原発巣手術時に頸部リンパ 節転移を認めたものがなかったため, 頸部郭清術を併 用した症例はなかった。リンパ節転移の有無は触診に より行った. 術後に放射線治療を追加したものが 2 例 あった。

多くの患者が交通事情, 経済的理由で術後の定期的 来院が困難であったため, 治療成績の検索は行えなかっ た. 確認できた範囲では, 術後原発巣の再発により死 亡したものは 3 例であった。 また後発転移を起こし再

\begin{tabular}{|c|c|c|c|c|}
\hline 病理組織型 & 症例数 & 男性 & 女性 & 平均年齢 \\
\hline 粘 表 皮 癌 & 8 例 & 5 例 & 3 例 & 47.4歳 \\
\hline 多形性腺腫内癌 & 7 & 2 & 5 & 49.0 \\
\hline 腺 & 6 & 5 & 1 & 57.7 \\
\hline 腺房 細胞 癌 & 6 & 3 & 3 & 46.8 \\
\hline 腺様囊胞癌 & 4 & 0 & 4 & 46.8 \\
\hline 乳頭様輬胞腺癌 & 4 & 4 & 0 & 37.5 \\
\hline 唾液腺導管癌 & 2 & 2 & 0 & 66.0 \\
\hline 筋 上 皮 癌 & 1 & 1 & 0 & 44 歳 \\
\hline 基底細胞腺癌 & 1 & 0 & 1 & 61 歳 \\
\hline 計 & 39例 & 22例 & 17例 & 49.6歳 \\
\hline
\end{tabular}

表 5 悪性腫瘍症例の性別および平均年齢

表 6 悪性腫瘍の治療 $(n=39)$

\begin{tabular}{lr}
\hline 浅葉切除 & 16 例 \\
耳下腺全摘 & 22 例 \\
深葉切除 & 1 例 \\
\hline 顔面神経保存 & 26 例 \\
(本幹切断再吻合 1 例 $)$ & \\
顔面神経一部切除 & \\
顔面神経全切除 & 11 例 \\
\hline
\end{tabular}


来院した症例はなかった.

多形性腺腫と Warthin 腫瘍以外の良性腫瘍29例で は, 腫瘍が深葉に存在したものは 5 例で, いずれも単 形性腺腫であった. 29例の手術法は浅葉切除が23例, 摘出が 4 例, 腫瘍周囲に一部正常腺組織を含めた被膜 外切除が 1 例, 耳下腺全摘が 1 例であった。

次に多形性腺腫とWarthin 腫瘍を比較検討した (表 7 ). 腫瘍の耳下腺内での位置は, 大部分が浅葉で, 深葉に存在したものは多形性腺腫で27例, Warthin 腫 瘍で 7 例, 耳下腺下極に存在したものが多形性腺腫で 6 例, Warthin 腫瘍で 7 例みられた.

手術方法は約 $90 \%$ が腫瘍を含めた浅葉切除で, 腫瘍 のみ摘出したものは多形性腺腫で14例, Warthin 腫瘍 で 2 例であった. 腫瘍摘出は, 耳下腺下極下端に腫瘍 が存在したもの, 副咽頭間隙に腫瘍の本体が存在した もの，および再発例ですでに浅葉が切除されていたも のに適用された。

腫瘍が深葉に存在した場合には 3 種類の手術が行わ れた. 最も多く用いられたのは, 浅葉切除に加え深葉

表 7 多形性腺腫と Warthin 腫瘍の手術法と合併症

\begin{tabular}{|c|c|c|}
\hline & 多形性腺腫 & Warthin 腫瘍 \\
\hline \multicolumn{3}{|l|}{ 腫瘍の存在位置 } \\
\hline 浅 葉 & 108例 & 35例 \\
\hline 深葉 & 27例 & 7例 \\
\hline 下 極 & 6例 & 7例 \\
\hline \multicolumn{3}{|l|}{ 切除方法 } \\
\hline 出 & 14例 & 2例 \\
\hline 浅葉切除 & 124例 & 45例 \\
\hline 浅葉＋哚葉の一部 & 2例 & 2例 \\
\hline 腫瘍＋周囲耳下腺切除 & 1例 & 0例 \\
\hline \multicolumn{3}{|l|}{ 顔面神経の剖出 } \\
\hline 末梢から & 67例 & 21例 \\
\hline 本幹から & 59例 & 26例 \\
\hline \multicolumn{3}{|l|}{ 合併症 } \\
\hline 神経損傷 & 24例 & 5例 \\
\hline 唾瘻 & 1例 & 1例 \\
\hline
\end{tabular}

の腫瘍を摘出する方法であった．また浅葉切除に加え 深葉の腫腸周囲健常組織を $5 \sim 10 \mathrm{~mm}$ 含めた切除が多 形性腺腫および Warthin 腫瘍の各 2 例に適用された。 また耳下腺表層の皮首から腫崵を触知せず，口腔内軟 口蓋部に突出していたもの，すなわち副咽頭間隙に存 在していた 2 例では, 口腔内から腫瘍を摘出した。両 側性に出現したWarthin 腫場の 4 例では， 3 例で両 側の浅葉切除を行い，1例では片側のみ浅葉切除を施 行, 対側は手術を行わなかった.

多形性腺腫二次症例の手術法は, 浅葉全体と深葉の 一部切除が 1 例, 浅葉切除 5 例, 周囲耳下腺を含めた 腫瘍切除が 1 例，および摘出が12例であった。

顔面神経は末梢側から剖出したものと中枢側から剖 出したものはほほ同数で, 両腫瘍間で剖出法に差はな かった.

合併症として顔面神経障害が多形性腺腫の 24 例, Warthin 腫瘍の 5 例に認められたが，いずれも早期に 回復した，その他, 唾漏の発生が 2 例に認められたが, 創の圧迫により, 早期に閉鎖した（表 7 ）.

顔面神経障害の発生頻度は両腫瘍で差はなく, 剖出 方法の間にも差は認められなかった（表 8 ).

手術後腫瘍の再発により再度来院したものは, 両腫 瘍一次症例にはなかったが, 多形性腺腫一次症例の 19 例中 5 例で再再発し，3 回目の手術（摘出）を施行し た。

\section{4. 耳下腺腫瘍の被膜の腫崵被覆状況}

多形性腺腫122例中腫湟全周に被膜が存在したもの は90例, 被覆が不完全であったものは32例であった。 また被膜内に腫湯細胞の胞巣を認めなかったものは71 例, 認めたものは51例であった．全周に被膜が存在し た症例のうち，被膜内に腫瘍胞巣が存在したものは34 例 $(37.8 \%)$, 被膜の被覆が不完全であった症例では 17 例 $(53.1 \%)$ と, 不完全被覆例で被膜内に腫瘍細胞が 存在したものがやや多かった（表 9 ）。この122例に二 次症例が17例含まれていたが, 全周に被膜が存在した ものは 12 例, 被覆が不完全であったものは 5 例であっ た. 被膜内に腫湯細胞が存在したものは，前者で 2 例， 後者で 1 例であった. 写真 1 は多形性腺腫の腫瘍実質 が被膜により正常組織と隔離されていたもので，写真 2 は被膜が欠如し, 腫瘍実質と正常組織が接していた

表 8 顔面神経剖出法の違いによる損傷頻度

\begin{tabular}{|c|c|c|c|c|c|c|}
\hline & \multicolumn{2}{|c|}{ 本幹 $\rightarrow$ 末梢 } & \multicolumn{2}{|c|}{ 末梢 $\rightarrow$ 本幹 } & \multicolumn{2}{|c|}{ 合 } \\
\hline & 症例数 & 損 傷 数 & 症例数 & 損 傷 数 & 症例数 & 損 傷 数 \\
\hline 多形 性 腺 腫 & 59 例 & 10例 $(16.9 \%)$ & 67 例 & 14例 $(20.9 \%)$ & 126例 & 24 例 $(19.0 \%)$ \\
\hline Warthin 腫 瘍 & 26例 & 2例（ $7.7 \%$ ) & 21例 & 3例 (14.3\%) & 47例 & 5 例 $(10.6 \%)$ \\
\hline 合 & 85 例 & 12例 (14.1\%) & 88例 & 17例（19.3\%） & 173例 & 29 例 $(16.8 \%)$ \\
\hline
\end{tabular}


表 9 多形性腺腫とWarthin 腫瘍の被膜の腫瘍被 覆状況と被膜内腫瘍細胞の有無

\begin{tabular}{|c|c|c|c|c|c|c|}
\hline $\begin{array}{l}\text { 被膜の腫瘍 } \\
\text { 被覆状 況 }\end{array}$ & \multicolumn{2}{|c|}{ 完全被覆 } & \multicolumn{2}{|c|}{ 不完全被覆 } & \multicolumn{2}{|c|}{ 合 計 } \\
\hline $\begin{array}{l}\text { 被膜内の腫 瘍 } \\
\text { 細胞胞巣の有無 }\end{array}$ & 無し & 有り & 無し & 有り & 無し & 有り \\
\hline \multirow{2}{*}{ 多形性腺腫 } & \multicolumn{2}{|c|}{90 例 $(73.8 \%)$} & \multicolumn{2}{|c|}{32 例 $(26.2 \%)$} & \multicolumn{2}{|c|}{ 122例 } \\
\hline & 56 例 & 34例 & 15例 & 17例 & 71例 & 51 例 \\
\hline $\begin{array}{l}\text { Warthin } \\
\text { 䀒 }\end{array}$ & \multicolumn{2}{|c|}{31 例 $(70.5 \%)$} & \multicolumn{2}{|c|}{ 12例 $(29.5 \%)$} & \multicolumn{2}{|c|}{ 43例 } \\
\hline 腫瘍 & 31 例 & 0 例 & 12例 & 0 例 & 43例 & 0 例 \\
\hline 合 計 & \multicolumn{2}{|c|}{87 例 +34 例 } & \multicolumn{2}{|c|}{27 例 +17 例 } & \multicolumn{2}{|c|}{ 165例 } \\
\hline
\end{tabular}

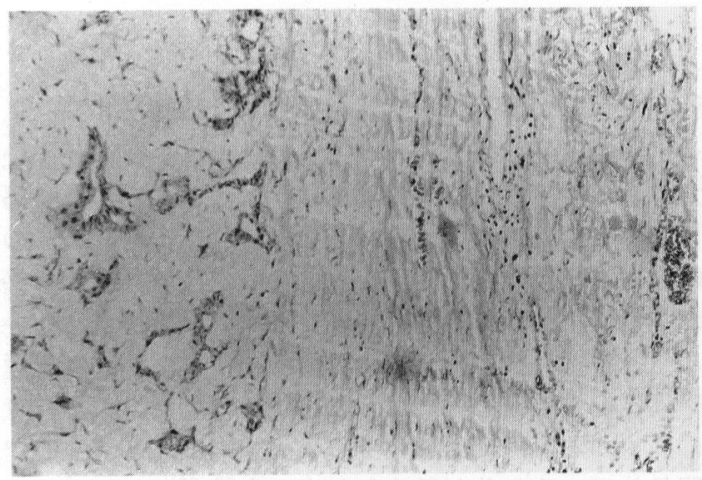

写真 1 被膜により腫瘍が被覆されている多形性腺 腫症例

左側が腫痬実質, 中央が腫瘍被膜. (HE 染色, 100倍)

\section{ものである(写真 1，2）。}

Warthin 腫瘍44例では, 腫瘍全周を被膜が被覆して いたものは31例, 被覆が不完全であったものは12例で, その被膜は非常に薄いものが多かった. また被膜が存 在しなかったものが1例であった. Warthin 腫瘍の被 膜内に腫瘍細胞が認められたものはなかった（表 9 ）. 写真 3 は比較的厚い被膜が腫瘍実質を被覆していた症 例であり，写真 4 は被膜が全周にわたって欠如してい た症例で, 腫瘍実質は直接正常耳下腺組織と接してい た (写真 3,4$)$. 多形性腺腫と Warthin 腫瘍の腫瘍 の大きさと被膜の形成状況との関係をみると, 多形性 腺腫の腫瘍最大径が $10 \mathrm{~mm}$ を越え $15 \mathrm{~mm}$ 以下, および 最大径が $30 \mathrm{~mm}$ を越え $35 \mathrm{~mm}$ 以下のもので不完全被 覆例が多かったが, その他の腫瘍の大きさでは多形性 腺腫もWarthin 腫瘍でも完全被覆例が不完全被覆例 よりも多くその割合もほぼ一定であった（表10).

多形性腺腫およびWarthin 腫瘍において, 被膜の

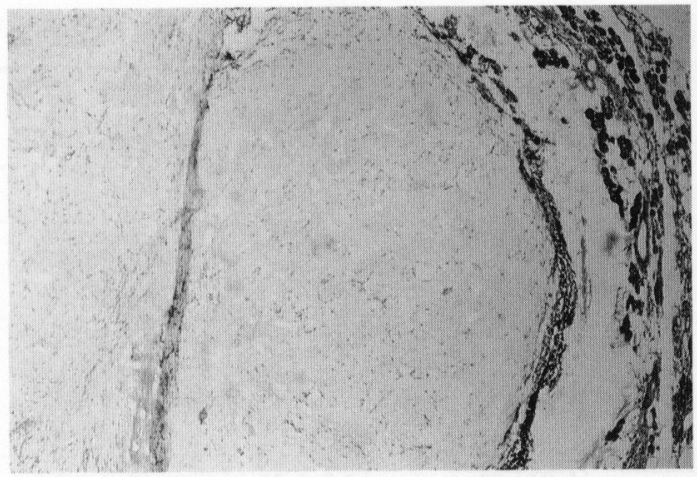

写真 2 明瞭な腫瘍被膜が存在しない多形性腺腫症例 右側が正常耳下腺組織で腫瘍組織との間に被膜はみ られない. (HE 染色, 40倍)

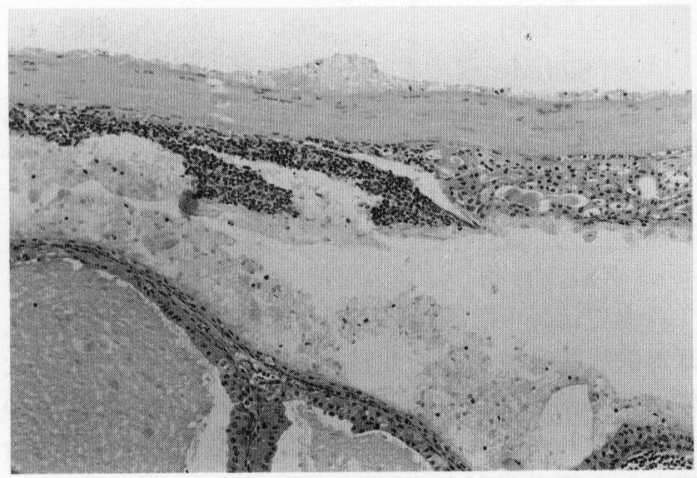

写真 3 明瞭な被膜を有するWarthin 腫瘍症例 下が腫瘍実質でその上に比較的厚い被膜が存在し ている.(HE 染色, 100倍)

一部が欠如していた症例全例について，切片上で被膜 欠如部の両側の被膜存在部を結ぶ被膜の仮想線を引い てみたところ，この仮想線を越えて腫瘍細胞が正常組 織側に明らかに突出していたものはなかった. また被 膜内に腫瘍細胞を認めたものでも, 被膜の外側に腫瘍 細胞が存在したものは検鏡した標本の範用内では認め られなかった。

これらの所見をまとめると, 被膜が腫瘍の全周を被 覆し, かつ被膜内に腫瘍細胞を認めないものでは, 腫 瘍組織と正常組織との間にある程度の距離が存在した. しかしその距離がきわめて小さい場合もあった.一方, 被膜の一部が欠如していたもの, および被膜が腫瘍を 被覆していても被膜内に腫瘍組織が存在していたもの では, 腫瘍組織と正常組織が接近ないしは接していた.

粘表皮癌の 8 例では全例明らかな被膜は存在せず, 腫瘍細胞は直接正常組織と接しており, 腫瘍本体から 蟹の足状に周囲組織内に浸潤していた. 腫瘍細胞の周 


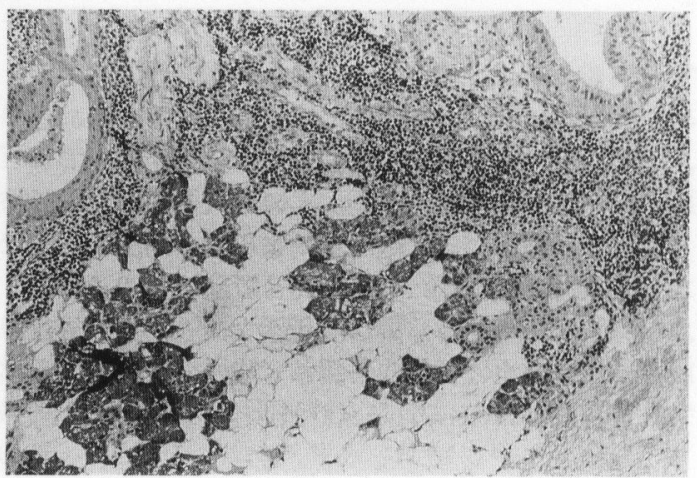

写真 4 腫瘍被膜が全く存在しなかった Warthin 腫瘍症例

上方が正常耳下腺組織, 中央から下方にかけて被膜 を介せず腫瘍実質が存在している. (HE 染色, 100倍)

囲正常組織内への最大浸潤距離はそれぞれ0.06, 0.065, 0.07, 0.07, 0.08, 0.09, 0.105および0.11mm であった.

\section{考察}

日本では耳下腺腫瘍の多数例の臨床的検討は少なく， 耳鼻咽喉科領域からの北村 2 $^{2}$ ，長尾 ${ }^{3}$ ) の千葉大 学のグループによる306例および451例の報告が最大の ものと思われる. 中国では耳下腺腫瘍は口腔外科で治 療される頻度が高く, 日常の手術の比較的大きな部分 を占めている。しかし，中国全土でみると耳下腺腫瘍 の手術ができる病院が少なく, 少数の病院に患者が集 中している可能性もある. 耳下腺腫瘍の発生頻度は世 界的にみると0.15〜 1.6 人 / 10 万人 ${ }^{4)}$ で日本では 1.7 人 /10万人 ${ }^{5)}$ とされているが, 中国での調査はなく, 日 本に比べ高頻度であるかどうかは不明である．また人 種差あるいは生活習慣による差があるとされており， カナダのイヌイットでは 9 年間に総人口 11,500 人のう ち 14 人に耳下腺腫瘍が発生し ${ }^{6)}$ ，これは 10 万人では 13.5 人に相当し，世界の報告の中で最も高い值と思わ れる.耳下腺では他の唾液腺と比較して良性腫瘍が多 く, 悪性腫瘍の比率は低いとされている. 涉猟しえた 文献 (表11, 12) 2,3,7 20) でみると, 良性腫瘍は張ら 8 ) の $66.2 \%$ から Woods ら ${ }^{13)}$ の $83.2 \%$ 範囲であり，本 研究の $84.9 \%$ は最も高いものであった，良性腫瘍のう ちでは多形性腺腫が最多である点はいずれの論文でも 同じであるが, その頻度は最も高いもので Eneroth $ら^{12)}$ の76.8\%, 最も低いものは北村ら 2$)$ の $37.9 \%$ あっ た. 日本での報告では，最も高い田中ら ${ }^{18)}$ で $68.9 \%$, 最も低いものはやはり北村ら ${ }^{2)}$ の $37.9 \%$ ありり, 中国 では47.5〜 70.5\% 7 10) と，国による差は大きくなく， 本研究の $54.7 \%$ は平均的な值であった. 本研究では良
表10 腫瘍の大きさと被膜の腫瘍被覆状況

\begin{tabular}{|c|c|c|c|c|c|}
\hline \multirow{2}{*}{$\begin{array}{l}\text { 被膜の腫啺 } \\
\text { 被 覆 状 海 } \\
\text { 最大径 }\end{array}$} & \multicolumn{2}{|c|}{ 多形性腺腫 } & \multicolumn{2}{|c|}{ Warthin 腫瘍 } & \multirow[b]{2}{*}{ 合計 } \\
\hline & 完全 & 不完全 & 完全 & 不完全 & \\
\hline$\leqq 10 \mathrm{~mm}$ & 5例 & 2例 & 0例 & 0例 & 7例 \\
\hline$\leqq 15 \mathrm{~mm}$ & 1 & 2 & 1 & 0 & 4 \\
\hline$\leqq 20 \mathrm{~mm}$ & 15 & 3 & 1 & 0 & 19 \\
\hline$\leqq 25 \mathrm{~mm}$ & 9 & 2 & 4 & 1 & 16 \\
\hline$\leqq 30 \mathrm{~mm}$ & 21 & 6 & 7 & 4 & 38 \\
\hline$\leqq 35 \mathrm{~mm}$ & 3 & 7 & 5 & 2 & 17 \\
\hline$\leqq 40 \mathrm{~mm}$ & 18 & 6 & 5 & 1 & 30 \\
\hline$\leqq 45 \mathrm{~mm}$ & 2 & 1 & 0 & 0 & 3 \\
\hline$\leqq 50 \mathrm{~mm}$ & 10 & 3 & 4 & 3 & 20 \\
\hline$>50 \mathrm{~mm}$ & 6 & 0 & 4 & 1 & 11 \\
\hline 合 計 & 90例 & 32例 & 31例 & 12例 & 165例 \\
\hline
\end{tabular}

性腫瘍は多いが, 多形性腺腫の割合は平均的であり, その原因は他の報告に比較して Warthin 腫瘍が多い 点にあると思われた。すすおわ本研究での耳下腺腫瘍 に占める Warthin 腫瘍の頻度は米国のSharkey ${ }^{14)} の$ 統計とほほ同程度で, 中国の他の報告 7 10)よりも高 かった. Warthin 腫瘍は喫煙との関連が指摘されてい る21 23) が, 今回の研究では Warthin 腫瘍患者の契煙 率は多形性腺腫患者の $50.0 \%$ と比較して $96.9 \%$ と有意 に高く, 契煙が Warthin 腫瘍の発症に何らかの形で 関与していることが示唆された. 唡 ${ }^{22,23)}$ は Warthin 腫瘍患者と多形性腺腫患者および正常中高年者を比 較し, Warthin 腫瘍患者で $98.2 \%$, 多形性腺腫患者で $47.4 \%$, 健康中高年者は $45.0 \%$, 本研究と同しくく Warthin 腫瘍患者での契煙率が有意に高いことを報 告している。また俞 ${ }^{24)}$ は Warthin 腫瘍の発生につい て, 胎生期にリンパ組織内に腺組織が迷入し，その後 喫煙により刺激され腫瘍が誘発されると推測している. 本研究において, Warthin 腫瘍は職業別では幹部に多 く, 性別では男性に多く, 年齢も多形性腺腫に比較し て高齢であった. 北京には中央および市政府, 共産党, 軍隊等に関連した公共機関, 企業の本社等が他の都市 に比較して格段に多く, 幹部という地位の人達が大勢 在住している。幹部には男性が多く, 中高年が多く, 喫煙者が多いこと等が, Warthin 腫湟が多い原因となっ ている可能性がある。これは同じ北京市内にある北京 医科大学の唡 ${ }^{24)}$ の報告において, Warthin 腫瘍の発

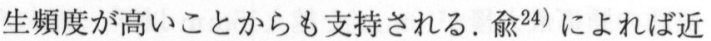
年 Warthin 腫瘍は増加の傾向にあり, 1962年〜1996年 までの35年間の1462例の耳下腺腫瘍中多形性腺腫は 1087例 $(74.4 \%)$, Warthin 腫瘍は216例（14.4\%）を占 め, Warthin 腫瘍の症例数の年代による変遷をみると, 1970 年〜 74年の間に $5.2 \%$ であったものが 1990 年代 
表11 耳下腺腫瘍の組織型別頻度

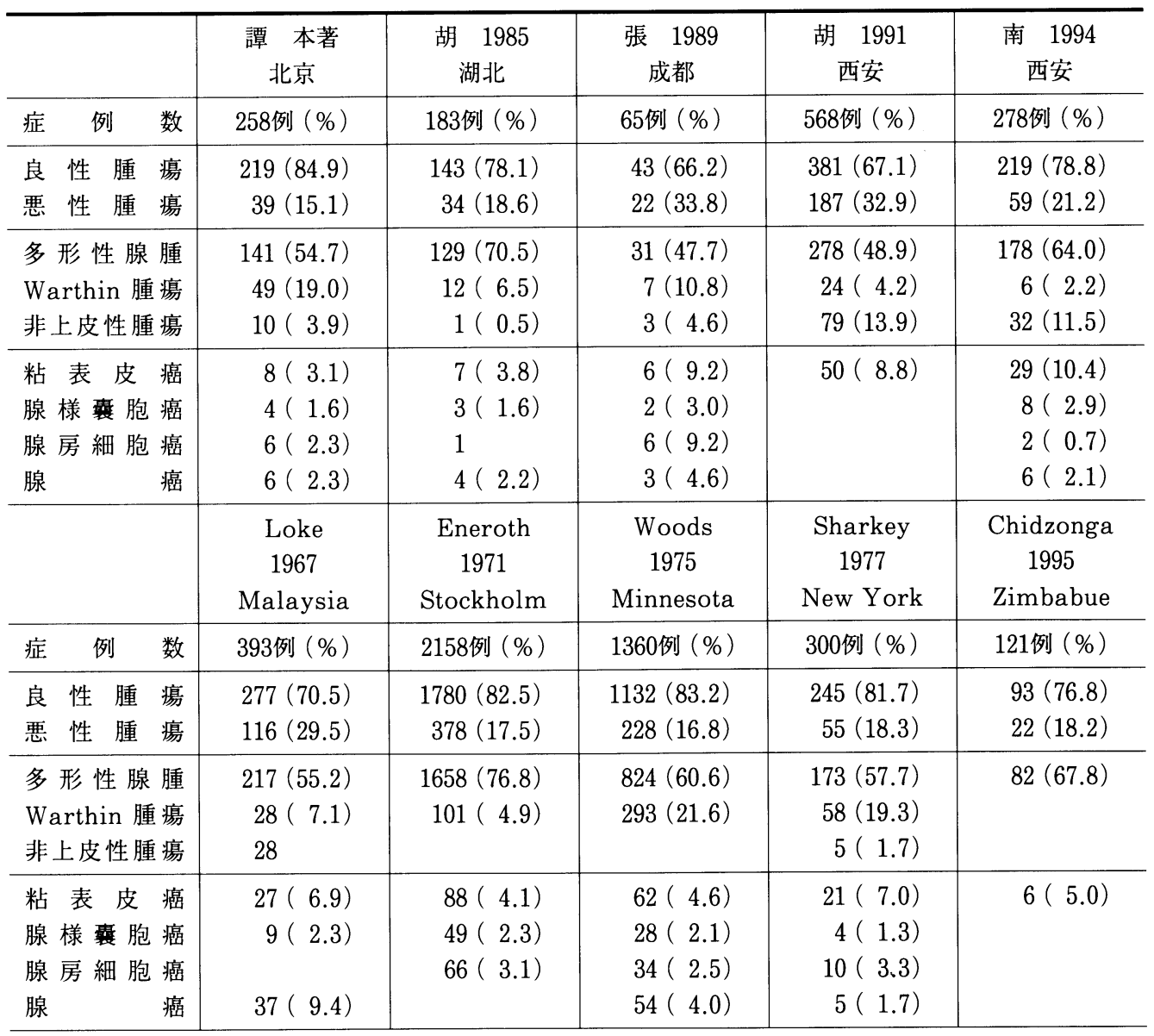

表12 日本における耳下腺腫瘍の組織型別頻度

\begin{tabular}{|c|c|c|c|c|c|c|}
\hline 報 告 者 & 症 例 数 & 良性腫瘍 & 覀性腫瘍 & 多形性腺腫 & Warthin 腫瘍 & 男女比 \\
\hline 北 村 (1971) & 306例（\%） & $207(67.6)$ & $99(32.4)$ & $116(37.9)$ & $9(2.9)$ & $8: 1$ \\
\hline 長 尾 (1977) & 451例 & $274(66.7)$ & $147(33.3)$ & $185(45.0)$ & $20(4.0)$ & \\
\hline 村 上 (1976) & 66例 & $35(53.0)$ & $25(37.9)$ & $25(37.9)$ & $6(9.1)$ & \\
\hline 野 崎（1981） & 81 例 & $64(79.0)$ & $17(21.0)$ & 44 & $5(6.1)$ & \\
\hline 田 中 (1990) & 61例 & 57 & .6) & & $10(16.4)$ & $7: 3$ \\
\hline 岩 崎 (1992) & 92例 & $70(75.8)$ & $22(24.2)$ & $51(56.0)$ & $15(16.5)$ & $11: 4$ \\
\hline 本 城 (1994) & 161例 & $131(82.4)$ & $30(18.6)$ & $100(62.1)$ & $25(15.5)$ & $3: 2$ \\
\hline
\end{tabular}

には $22.5 \%$ 占めるに至ったとのことである．日本で の報告においても，表12に示すように，1990年代の

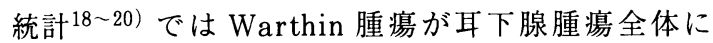
占める割合は15.5 16.5\%であり，1981年以前の報 告 $2,3,16,17)$ が2.9 9.1\%であったのと比較すると, 近
年 Warthin 腫湯は増加していることが推測される. Ebbs ら ${ }^{25)}$ は英国において，Woods ら ${ }^{13)}$ は米国にお いても近年 Warthin 腫湟の増加を報告している。一 方, 中国の内陸部である西安からの比較的新しい報 告 9,10$)$ では Warthin 腫腸は $2.2 \sim 4.2 \%$ と少なく, 中 
国国内でも発生頻度に差があり，地域ないしは経済発 展の格差が反映されているようで興味深い.

口口腔医院では耳下腺腫瘍の治療として, 悪性腫 瘍も良性腫瘍も全例手術が行われた. 悪性腫瘍では安 全域を大きくとった浅葉切除あるいは耳下腺全摘が適 用されたが，良性である多形性腺腫およびWarthin 腫瘍に対しても腫瘍の大きさと関係なく浅葉切除を行っ たものが多かった，中国では人口に対する病院数が少 なく, 国土も広く, 患者が遠隔地から来院することも 少なくなく, さらに交通事情, 経済事情等から術後の 通院が困難な場合が多い，そのため術後の再発が極力 起こらない治療を行う必要がある. 本研究では多形性 腺腫およびWarthin 腫瘍の一次症例においては再発 のため再来院したものはなかったが, 残念ながら多く の症例でリコールができず, 治療の長期成績は評価で きなかった。

著者らは耳下腺腫瘍の術前診断として, 触診等の臨 床診断, および必要に応じてエックス線造影撮影を行 い, 良性か悪性かの判定を行っている。触診での周囲 組織との癒着の有無およびエックス線造影像での導管 からの造影剂の溢出像, 腫瘍存在部の非造影領域の輪 郭等から, 良性か悪性かの区別はほぼ可能であると考 える. しかし, 耳下腺腫場の中で最も頻度が高い多形 性腺腫, およびそれに次ぐ頻度の Warthin 腫瘍は共 に被膜が薄く，時に部分的に欠損していることもあり， 単純摘出では再発することがある ${ }^{7,26)}$ とされている. 一方, 術前に腫瘍被膜の被覆が完全か不完全か, さら には被膜内への腫瘍細胞の浸潤の有無を判定すること は不可能であり，またまれに低悪性の粘表皮癌等が良 性として手術されることもあり，個々の腫瘍の状況に 正確に対応する手術法を選択することは困難である．

被膜による腫湯被覆状況を区分すると，(1)被膜が完 全に腫瘍を被覆しているもの, (2)被膜の被覆が不完全 なもの, (3)被膜が欠如しているもの，の 3 種類に加え て, a. 被膜内に腫場細胞が存在しないもの, b. 被膜内 に腫瘍細胞が存在するもの, とになり, (1)(2)(3)と a. b. で 5 種類の組み合わせができる. Warthin 腫瘍は別名 腺リンパ腫と呼ばれるが, 腫瘍内のリンパ系細胞はす べて腫瘍間質 $27 \sim 29)$ とされている. 大部分の Warthin 腫瘍の被膜内にリンパ系細胞を認めたが, 腫瘍細胞 ではないのでこれを除外すると，それぞれの症例数は (1) - a が多形性腺腫で56例, Warthin 腫瘍で 31 例, (1)-b は多形性腺腺腫で 34 例, Warthin 腫瘍で 0 例, (2) - a は多形性腺腫で 15 例, Warthin 腫瘍で12例, (2)- b は多形性腺腫で 17例, Warthin 腫瘍で 0 例, (3)は Warthin 腫瘍の 1 例であった。

被膜が腫瘍の全周を被覆し被膜内に腫瘍細胞が存在 しないもの（1－a）では, 腫瘍実質は正常組織から ほほ隔離されていると考えられる．被膜が腫瘍全周 を被覆しているが被膜内に腫瘍細胞が存在するもの (1)-b), 被膜が一部欠如し被膜内に腫瘍細胞が存在 しないもの (2)-a)，および被膜内に腫場細胞が存在. するもの (2)-b) では, 腫瘍実質は正常組織と接して いるかきわめて近接した状況にある. 症例数は 1 例の みであったが, Warthin 腫犜で被膜が全く存在しなかっ たものが認められた。これらの 5 種類の被膜の被覆状 態のうち, (1)- $\mathrm{a}$ では腫場の単純摘出が可能かと考え られた. (1)-bでは腫碭は被膜により完全に被覆され ているが, 単純摘出で被膜を損傷すれば腫瘍が残存す る可能性がある.さらに被膜の被覆が不完全な(2)一 と(2)一b 拉よび被膜が存在しない(3)では，単純摘出で は腫瘍が残存する可能性が十分にある.すなわち被膜 の状況から摘出でも再発の可能性が低いと思われたも のは, 多形性腺腫では122例中56例, Warthin 腫瘍では 41 例中 31 例で, 合わせて 166 例中 87 例 $(52.4 \%)$ と, 約 半数であった.しかし，今回は各症例について $2 \sim 3$ 枚の全割切片での検討であり, 連続切片による所見で はないので, 被膜による腫瘍の完全被覆の比率は実際 にはもう少し低いと推測される。

諸家の報告をみると，耳下腺の良性腫瘍に対する手 術は, 腫瘍を含め浅葉，あるいは浅葉と深葉の全切 除を行うもの $2,7,10,16,19,29 \sim 32)$, 腫湯周囲に耳下腺 の正常組織を一部含めて切除するもの（被膜外切 除 $)^{20,33 \sim 36)}$, および腫瘍摘出11,37) を行うものとがあ る. 著者らは浅葉切除を行っているが, 浅葉切除であ れば,もし結果的に悪性腫瘍であった場合でも安全域 は十分に確保される. 被膜外切除では良性腫漡に対し ては安全域は確保されるが, 悪性腫瘍であった場合に は不十分となる。今回の研究では, 多形性腺腫と Warthin 腫瘍で被膜が久如していた場合でも，腫瘍実 質が正常組織内に大きく突出している像はみられなかっ た.しかし, 多形性腺腫では腫瘍の一部が被膜を穿孔 して被膜外に増殖していた ${ }^{38)}$ との報告もあり，正常組 織をある程度含めて切除する必要がある. その点を考 慮するともうひとつの方法として, 腫瘍がそれほど大 きくない場合には, 耳下腺浅葉の部分切除 ${ }^{18,25)}$ も選 択肢に入れることができる. 今回の検索では粘表皮癌 では全例被膜は存在しなかったが, 正常組織内への腫 場細胞の浸潤は浅く, 浅葉に存在する場合には浅葉切 除で十分対応できると考えられた。

本研究での被膜の腫瘍被覆状況の検索は, 術前にこ れを行うことはできないので手術法決定には応用でき ないが, 予後推定には有用であると考えられた。

\section{結 論}

1. 1987年から 1996年までの10年間に】医科大学 附属—口腔医院口腔顎顔面外科で治療を行った耳下 腺腫瘍258例について検討した。

2.このうち覀性腫瘍は39例, 良性腫瘍が219例, 良 
性腫瘍では141例が多形性腺腫, 49例が Warthin 腫瘍 と, Warthin腫瘍が他の報告に比較して多かった。

3. 多形性腺腫と Warthin 腫瘍を比較すると, 性別 では多形性腺腫は女性に多く, Warthin 腫瘍は男性に 多く, 平均年齢は多形性腺腫に比べWarthin 腫瘍で 高く, この 2 項目で両腫瘍に有意差を認めた.

4. Warthin 腫瘍の患者で有意に喫煙率が高く (96.9\%), Warthin 腫瘍発生に喫煙が関与している可 能性が示唆された。

5 . 治療は全例手術が行われ, 悪性腫瘍では浅葉切 除が16例, 耳下腺全摘が 22 例, 深葉切除が 1 例であっ た. 多形性腺腫㧍よび Warthin 腫瘍でも大部分で浅 葉切除が行われた。

6 . 術後, 顔面神経麻痺が16.8\%に認められたが, 全 例早期に完全回復した.また顔面神経の剖出法の違い による神経麻㾇の出現頻度には差はなかった。

7. 被膜が腫湯を完全に被覆していたものは多形性 腺腫で73.8\%, Warthin 腫瘍では70.5\%と，ともに約 $30 \%$ 症例で被膜による腫瘍の被覆は不完全であった. 被膜内に腫瘍実質細胞が存在していたものは, 多形性 腺腫で $41.8 \%$ であった. 粘表皮癌では全例被膜は存在 しなかった。

8. 多形性腺腫およびWarthin 腫瘍の被膜の腫瘍 の被覆状況から手術法を考察すると, 浅葉に存在する 腫瘍では, 浅葉切除あるいは浅葉部分切除が必要であ ると思われた．また中国の国内事情，粘表皮癌などの 低悪性の腫瘍が含まれる可能性を考慮すると，臨床的 に良性腫瘍と診断されても浅葉切除は妥当な治療法と 思われた。

本論文の要旨は第13回国際口腔顎顔面外科学会（1997 年10月20日〜 24日, 京都) ならびに第43回日本口腔外科学 会総会 (1998年10月 7，8 日,松本)において発表した。

稿を終わるにあたり，本論文に対し御懇篤なる御指導， 御校閲を賜りました鶴見大学歯学部口腔外科学第一講座 瀬戸晥一教授, ならびに首都医科大学北京口腔医院口腔 顎顔面外科朱宣智教授に本心より深謝いたします。また 病理組織所見について御指導御助言をいただきました首 都医科大学付属北京口腔医院病理科張中儀教授, 王寧副 教授,ならびに本研究に対し惜しみない御協力を賜りま した同口腔顎顔面外科隋良朋教授をはじめ教室員の皆様 に深甚なる感謝の意を表します。

\section{引用 文 献}

1) Seifert, G., Sobin, I.H.: Histological classification of salivary gland tumours. In: World Heath Organization. International histological classification of tumours. Berlin, Springer-Verlag 1991.

2) 北村 武, 金子敏郎, 他 : 耳下腺腫瘍の臨床一
教室20年間の統計的観察-耳鼻臨床 64 (増): 1286-1301 1971.

3）長尾孝一, 松菩理, 他: 耳下腺腫瘍の臨床病理 学的研究 癌の臨床 23: 519-526 1977.

4）俞光岩：第13章涎腺上皮性腫瘤 俞光岩編：涎 腺疾病 (第 1 版). 北京医科大学中国協和医科大 学聯合出版社, 北京, 1994年, 111-112頁.

5) 藤田洋祐, 金子敏郎, 他 : 耳下腺腫瘍の臨床統 計 奥田稔, 金子敏郎編 : 耳下腺腫瘍一その基 礎と臨床一-(第 1 版). 文光堂, 東京, 1987年, 115-122頁.

6) Wallance, A.C., MacDougall, J.T., et al.: Salivary gland tumors in Canadian Eskimos. Cancer 16: 1338-1353 1963.

7）胡樹立, 李金栄, 他 : 腮腺腫瘤183例分析. 華西 口腔医学雑誌 6: 248-251 1988.

8）張建設, 陳佐華, 他 : 腮腺腫瘤 65 例臨床及病理 分析. 口腔医学 9: 7-9 1989.

9）胡永升, 張引成, 他: 腮腺腫瘤568例臨床分析. 西安医科大学報 12: 266-268 1991 .

10）南平, 肖光裕, 他 : 腮腺腫瘤278例臨床及病理 分析. 第四軍医大学学報 15: 237-238 1994.

11) Loke, Y.W.: Salivary gland tumours in Malaya. Br J Cancer 21: 665-674 1967.

12) Eneroth, C. -M.: Salivary gland tumors in the parotid gland, submandibular gland, and the palate region. Cancer 27: 1415-1418 1971.

13) Woods, J.E., Chong, G.C., et al.: Experience with 1360 primary parotid tumors. Am J of Surg 130: 460-462 1975.

14) Sharky, F.H.: Systematic evaluation of the world health organization classification of salivary gland tumors. A clinicopathologic study of 366 cases. AJCP 67: 272-278 1977 .

15) Chidzonga, M.M., Lopez Perez, V.M., et al.: Salivary gland tumours in Zimbabwe: report of 282 cases. Int J Oral Maxillofac Surg 24: 293-297 1995.

16）村上 泰, 猪 忠彦, 他: 耳下腺腫瘍 70 症例の 治療経験. 耳喉 48: 589-602 1976.

17）野崎秋一, 三吉康郎, 他：大唾液腺腫瘍の臨床 統計的観察. 耳鼻臨床 74增 2: 1044-1053 1981.

18）田中 治, 松本雅央, 他 : 大喠液腺腫場の臨床一 最近 7 年間の統計的観察-. 耳鼻臨床（補）37: 286-292 1990.

19）岩崎幸司, 石崎久義, 他 : 大唾液腺腫瘍の臨床 統計的観察. 耳鼻臨床（補）60: 64-71 1992.

20）本城祐一郎, 奥村隆司, 他 : 大喠液腺腫瘍の統 計的観察. 頭頭部腫瘍 20: 140-144 1994.

21) Kotwall, C.A.: Smoking as an etiologic factor in the development of Warthin's tumor of the parotid gland. Am J Surg 164: 646-647 1992. 
22）俞光岩, 柳暁冰, 他: 吸烟与腮腺沃辛瘤的発病. 中華口腔医学雑誌 30: 195-197 1995.

23) Yu, G.Y., Liu, X.B., et al.: Smoking and the development of Warthin's tumour of the parotid gland. Brit J Oral \& Maxillofac Surg 36: 183-185 1998.

24）俞光岩, 劉兆菊, 他: 腮腺沃辛瘤的綜合研究. 中華口腔医学会雑誌 34: 187-189 1999.

25) Ebbs, S.R. and Webb, A.J.: Adenolymphoma of the parotid: aetiology, diagnosis and treatment. Br J Surg 73: 627-630 1986.

26) Chang, E.Z.: Surgical treatment of pleomorphic adenoma of the parotid gland; report of 110 cases. J Oral Maxillofac Surg 43: 680-682 1985.

27）丸山 毅 : 耳下腺 adenolymphoma の病理組 織学的研究. 日耳鼻 89: 66-80 1986.

28）石川悟朗（監修）：口腔病理学 II 改訂版. 永 末書店, 1982年, 東京, 731-735頁.

29）菅野春夫, 小林 博 (編) : 臨床病理学 初版. 朝 倉書店, 1970年, 東京, 359-363頁.

30) Eneroth, C. -M. and Hamberger, C. -A.: Principles of treatment of different types of parotid tumors. Laryngoscope 84: 173217401974.
31) Richardson, G.S., Dickason, W.L., et al.: Tumors of salivary glands. Plast \& Reconstr Surg 55: 131-138 1975.

32) Wang, D., Liu, S., et al.: A modified centripetal approach to parotidectomy. J Oral Maxillofac Surg 43: 14-19 1985.

33）北村 武, 戸川 清, 他：耳下腺の外科一特に 腫瘍の際の問題点一。耳鼻臨床 64:339-348 1971.

34）小池吉郎, 鈴木八郎：耳下腺腫瘍の診断, 治療 についての 2，3の問題点. 耳鼻 24: 917-929 1978.

35）奥田 稔, 坂口幸作：大喠液腺腫瘍 100 症例の 臨床. 耳喉 53: 1009-1016 1981.

36) McGurk, M., Renehan, A. et al.: Clinical significance of the tumour capsule in the treatment of parotid pleomorphic adenomas. Br J Surg 83: 1747-1749 1996.

37) Yu, G.Y., Ma, D.Q., et al.: Local excision of the parotid gland in the treatment of Warthin's tumour. Br J Oral \& Maxillofac Surg 36: 186-189 1998.

38) Ellis, G.L. and Auclarir, P.L.: Atlas of Tumor Pathology, Tumors of the Salivary Glands. Armed Forces Institute of Pathology, Washinton DC, 1996, p.39-50. 